Mishra et al., Afr J Tradit Complement Altern Med. (2013) 10(3):390-396 http://dx.doi.org/10.4314/ajtcam.v10i3.1

\title{
STANDARDIZATION OF A TRADITIONAL POLYHERBO-MINERAL FORMULATION- BRAHMI VATI
}

\author{
Amrita Mishra ${ }^{1,2 *}$, Arun K Mishra ${ }^{1}$, Ashoke K Ghosh ${ }^{1}$, Shivesh $\mathrm{Jha}^{2}$ \\ ${ }^{1}$ Pharmacognosy Research Laboratory, School of Pharmaceutical Sciences, IFTM University, \\ Lodipur-Rajput, Moradabad-244001, India \\ ${ }^{2}$ Department of Pharmaceutical Sciences, Birla Institute of Technology, Mesra, Ranchi, 835215, India. \\ *Email: amrita azam@rediffmail.com
}

\begin{abstract}
The present study deals with standardization of an in-house standard preparation and three marketed samples of Brahmi vati, which is a traditional medicine known to be effective in mental disorders, convulsions, weak memory, high fever and hysteria. Preparation and standardization have been done by following modern scientific quality control procedures for raw material and the finished products. The scanning electron microscopic (SEM) analysis showed the reduction of metals and minerals (particle size range 2-5 $\mu \mathrm{m}$ ) which indicates the proper preparation of bhasmas, the important ingredient of Brahmi vati. Findings of EDX analysis of all samples of Brahmi vati suggested the absence of Gold, an important constituent of Brahmi vati in two marketed samples. All the samples of Brahmi vati were subjected to quantitative estimation of Bacoside A (marker compound) by HPTLC technique. Extraction of the samples was done in methanol and the chromatograms were developed in Butanol: Glacial acetic acid: water (4.5:0.5:5 v/v) and detected at 225nm. The regression analysis of calibration plots of Bacoside A exhibited linear relationship in the concentration range of 50-300 ng, while the \% recovery was found to be $96.06 \% \mathrm{w} / \mathrm{w}$, thus proving the accuracy and precision of the analysis. The Bacoside A content in the in-house preparation was found to be higher than that of the commercial samples. The proposed HPTLC method was found to be rapid, simple and accurate for quantitative estimation of Bacoside $\mathrm{A}$ in different formulations. The results of this study could be used as a model data in the standardization of Brahmi vati.
\end{abstract}

Keywords: Brahmi vati( BV); Standardization; EDX; HPTLC; Bacoside-A

\section{Introduction}

Ayurveda, the ancient system of plant based medicines is gaining recognition throughout the world and many herbal drugs are now clinically tested and accepted for manufacturing (Gold frank L, et al 1982; Vulto A.G, et al 1988). However, one of the impediments in the acceptance of the ancient systems of medical preparation is the lack of standard quality control profiles (Bagul and Rajani, 2005). The quality of herbal medicine, that is, the profile of the constituents in the final product has implication in efficacy and safety. Due to the complex nature and inherent variability of the chemical constituents of the plant based drugs, it is difficult to establish quality control parameters therefore modern analytical techniques are expected to help in circumventing this problem. Ayurvedic medicines prepared in the form of tablets or pills are known as Vati and Gutika. These are made of one or more drugs of plant, animal or mineral origin. Brahmi vati (BV), a polyherbo-mineral formulation, consists of Brahmi (Bacopa monnieri) and another thirty six ingredients including nine bhasmas and pisties. The formulation is official in the Ayurvedic Formulary of India, Part II and claimed to be therapeutically useful in the treatment of all types of mental disorders, vertigo, heart weakness, high fever, convulsion, hysteria and mental weakness (The Ayurvedic Formulary of India, 1976). In the present study, one batch of BV was prepared in laboratory with standard materials (IBV) and three commercial samples (BV1, BV2 and BV2) from market were collected. These four samples were subjected to physico-chemical, pharmaceutical and energy dispersive X ray spectroscopy analysis (EDX). The amount of Bacoside A - one of the saponine of Brahmi — was analyzed quantitatively in all four samples. These parameters can be compared with any commercial formulation available in the market for evaluating its purity and quality. The proposed method has been validated as per ICH guidelines (ICH, 1994 and 1996). Bacosides are secondary metabolites produced by the plant. The scientists assumed bacoside A to be an indicator of the presence of brahmi (Marker compounds of selected Ayurvedic drugs, 2009).

In spite of the large number of herbal formulations available in the market, standards for their quality are yet to be laid for many of them (Eapen Saumy M.S, et al 2002; Patel K.N, 1996). It is therefore, imperative to develop fast, sensitive and accurate quality control tests for Ayurvedic formulations which will be in alignment with modern technology. In the literature survey no scientific study has been conducted to standardize this BV so far. Hence, a scientific investigation was undertaken to evaluate BV.

\section{Materials and Methods}

Analytical Reagent grade butanol, glacial acetic acid and methanol were obtained from S.D. Fine Chem Ltd.(Mumbai, India). Pure Bacoside A was obtained from IIIM, Jammu, India as gift samples. Pre-coated silica gel 60 F254 TLC aluminum plates (10 x $10 \mathrm{cms}, 0.2 \mathrm{~mm}$ thick) were obtained from E.Merck Ltd. (Mumbai, India). 
Mishra et al., Afr J Tradit Complement Altern Med. (2013) 10(3):390-396 http://dx.doi.org/10.4314/ajtcam.v10i3.1

\section{Crude herbs and minerals}

All required herbs and minerals (Table 1) were purchased from local markets and authenticated by Department of botany and department of Rasa Shashtra, Banaras Hindu University, Varanasi, India. These plant materials were standardized following The Ayurvedic Pharmacopoeia of India. As per the results, the low quality batches were replaced.

Table 1: Ingredients of Brahmi vati

\begin{tabular}{|c|c|c|c|}
\hline Name of Ingredients & Plant/mineral/metal name & Parts used & Main constituents \\
\hline Nutmeg & Myristica fragrance Hoult. & Seed & Isoeugenol, methyl-eugenol, eugenol, myrcene, quercetin \\
\hline Clove & Eugenia carophyllus Thunb. & Flower bud & Eugenol, eugenyl acetate, beta-caryophyllene, tannins \\
\hline Saussurea & Saussurea lappa C.B. Clarke. & Root & Costunolide, Isodihydrocostunolide, cynaropicrin. \\
\hline Mace & Myristica fragrance Hoult. & Aril/Mace & $\alpha$ - pinene, $\beta$ - pinene, limonene, linoleic acid, palmitic acid \\
\hline Caraway & Carum carvi Linn. & Fruit & Carvacrol, carvone, $\alpha$-pinene, limonene, $\gamma$-terpinene, linalool, \\
\hline Long pepper & Piper longum Linn. & Fruit & Piperine, piperidine, piperitine, $\alpha$ - pinene, sesquiterpenes. \\
\hline Cinnamon & Cinnamomum zeylanicum Blume. & Stem bark & Cinnamaldehyde , $\alpha$ - pinene, $\beta$ - pinene, ethylcinnamate, eugenol \\
\hline Anise & Pimpinella anisum Linn. & Fruit & Eugenol trans-anethole, methylchavicol, coumarins, scopoletin \\
\hline Withania & Withania somnifera Dunal. & Root & Withanone, withaferin A, withanolide A, withanolide D \\
\hline Pallitory & Anacyclus pyrethrum Linn. & Root & Pyrethrine, inulin, volatile oil. \\
\hline Coriander & Corriandrum sativum Linn & Fruit & Coriandrol, borneol, citronwllol, pyrazine, pyridine, Coriandrin \\
\hline Vansalocana & Bambusa arundinacea Retz. & $\begin{array}{c}\text { Siliceous } \\
\text { concretions }\end{array}$ & Cellulose, pentosans, silica. \\
\hline Cardamom & $\begin{array}{l}\text { Elettaria cardamomum White et } \\
\text { Mason. }\end{array}$ & Seed & Cineole, Borneol, Teripineol \\
\hline Sankhapuspi & Evolvulas alsinoides Linn. & Plant & Betaine, shankhapushpine and evolvine. \\
\hline Sandal wood & Centalum album Linn. & Heart wood & Santalol, santene, alcohols-santenol, \\
\hline Fennal & Foeniculum vulgare Mill. & Fruit & trans-Anethole, estragole, fenchone, quercetin, arabinoside \\
\hline Patra & Cinnamomum tamala Fr.Nees. & Leaf & Alpha-pinene, Benzaldehyde ,Beta Phellandrene, Linalool, \\
\hline Mesua & Mesua ferra Linn. & Steman & Ferruol- A, Mesuaferrone-A, Mesuaferrone B, Mesuein. \\
\hline Mastic & Pistacia lentiscus Linn & Exudate & Alpha and beta masticoresins, masticin, mastic acid, masticoresen \\
\hline Pippalamula & Piper longum Linn. & Root & Piperine, cepharadione A, cepharadione B. \\
\hline Lead War & Plumbago zeylanica Linn. & Root & Plumbagin, naphthoquinones, binaphthoquinones, coumarins, \\
\hline Galanga & Alpinia galangal Linn. & Rhizome & Galangin, Kaempherol, Acetoxyeugenol acetate, Hydroxychavicol \\
\hline Abelmoschus & Abelmoschus moschatus Medik. & Seed & ((Z)-7-hexadecen-16-olide) and (Z)-5-tetradecen-14-olide \\
\hline $\begin{array}{l}\text { Thyme Leaved } \\
\text { Gratiola }\end{array}$ & Bacopa monnieri Linn. & Plant & $\begin{array}{l}\text { Bacoside } A_{3} \text {, Bacoside II, bacogenin } A_{1}, A_{2}, A_{3} \text {, bacopasaponins } \\
A, B \text { and } C \text {, pseudojujubogenin }\end{array}$ \\
\hline Indian jalap & Operculina turpethum Linn. & Root & Turpethin, Turpethinic acids- A, B, C, D, \& E \\
\hline Eagle wood & Aquilaria agollochal Roxb. & Heart wood & Octacosane, naphthalene. \\
\hline Saffron & Crocus sativus Linn. & Stigma & Crocin, safranal, picrocrocin \\
\hline Abhraka bhasma & Abhraka & Biotite mica & $\mathrm{K}(\mathrm{Mg}, \mathrm{Fe})_{3} \mathrm{AlSi}_{3} \mathrm{O}_{10}(\mathrm{Fe}, \mathrm{OH})_{2}$ \\
\hline Mukta bhasma & Mukta & Pearl & $\mathrm{CaCO}_{3}$ \\
\hline Akik bhasma & Akik & Agate & $\mathrm{SiO}_{2}$ \\
\hline Praval bhasma & Praval & Red coral & $\mathrm{CaCO}_{3}, \mathrm{Mg}$ \\
\hline Candrodaya & Gandhak and parad & $\begin{array}{l}\text { Sulphur and } \\
\text { Murcury }\end{array}$ & $\mathrm{S}, \mathrm{Hg}$ \\
\hline Svarna bhasma & Svarna & Gold foil & $\mathrm{Au}$ \\
\hline Kaharuba pisti & Kaharuba & Amber & Diterpenes $\left(\mathrm{C}_{20} \mathrm{H}_{32}\right)$ and trienes \\
\hline Manikya pisti & Manikya & Ruby & $\mathrm{Al}_{2} \mathrm{O}_{3}$ \\
\hline
\end{tabular}


Mishra et al., Afr J Tradit Complement Altern Med. (2013) 10(3):390-396 http://dx.doi.org/10.4314/ajtcam.v10i3.1

\section{Commercial samples of Brahmi vati}

Three marketed samples of Brahmi vati were purchased from three different manufacturers from local market and labeled as BV1, BV2 and BV3.

\section{Preparation of bhasma and pisties}

For in house preparation of Brahmi vati, all minerals and metals were processed to get respective bhasma and pistis. The process was performed under the supervision of a Ayurvedic practitioner under standard laboratory conditions. Bhasma were prepared by traditional process, which involved two steps- shodhana (purification) and maran (calcinations ant rosting) of gem/mineral/metals with specified plant materials ( Prakash B, 1997). Akik bhasma, Abhrak bhasma, Praval bhasma and Mukta bhasma were prepared by this process. Kaharuba pisti, Manikya pisti and Sangryasaba pisti were prepared by triturating the minerals with specified plant materials (The Ayurvedic Formulary of India, 1976). Chandrodaya and Swarna bhasma were purchased from Ayurvedic Pharmacy, Institute of medical sciences, Banaras Hindu University, Varanasi. All bhasma and pistis were packed in glass bottles, labeled and stored in cool and hygienic place. SEM analysis was performed to check the proper preparation of bhasma which is indicated by the reduction in particle size to the micro meter range (Mohaptra and Jha, 2010).

\section{In-house preparation of Brahmi vati}

After this all plant materials were individually pulverized and sieved to find respected fine powders. For preparation of BV, powdered Candrodaya, Saffron, Abelmoschus and Ambara were mixed together. To this mixture, one by one bhasma and pistis were added and mixed well. Thereafter powders of plant materials along with fresh juice of Bacopa monnieri were added to the mixture and ted. Pills about $250 \mathrm{mg}$ were prepared by hand rolling dried in shade and packed in sterilized polyethylene pouches, labeled as IBV and stored in a cool, hygienic place (Figure 1) (The Ayurvedic Formulary of India ,1976).

\section{Evaluation Physico-chemical and Pharmaceutical parameters}

For standardization of BV, physicochemical properties were evaluated for all samples (Mukharjee P.K, 2002). BV is a tablet formulation so pharmaceutical parameters as friability, weight variation, hardness, disintegration time were evaluated (Pattanayaka P, 2011; Lohar S.D, 2009)

\section{Energy dispersive $\mathrm{X}$ ray spectroscopy analysis}

As BV consists of bhasma and pistis, which are derived from minerals and metals, elemental composition of BV was evaluated by EDX analysis. The analysis was performed in the department of Physics, Banaras Hindu University, India. EDAX micro analyst, model- zaluzec with SUTW-Sapphire detector was used for this purpose. (Sudhaparimala S, et al 2011; Singh S.K, et al 2010).

\section{Preparation of standard solution and samples for HPTLC}

A reference standard solution of Bacoside A $(10 \mu \mathrm{g} / \mathrm{ml})$ was prepared by dissolving $1 \mathrm{mg}$ of accurately weighed Bacoside $\mathrm{A}$ in methanol by sonication in ultrasonic water bath to dissolve and making up the volume to $100 \mathrm{ml}$ with methanol. The stock solution was further diluted with methanol to give a standard solution of bacoside (50ng/ $\mu \mathrm{l}) .250 \mathrm{mg}$ of IBV, BV1, BV2 and BV3 were extracted in methanol sapartly and extracts were sonicated, filtered through Whatman filter paper No1 and the final volumes were made up to $25 \mathrm{ml}$ with methanol.

\section{Chromatographic Conditions (For bacoside A )}

Stationary phase: Pre-coated silica gel 60F254 TLC plate $(10$ x $10 \mathrm{cms}, 0.2 \mathrm{~mm}$ thickness). Mobile phase: Butanol: Glacial acetic acid: water (4.5:0.5:5v/v), Saturation time: 15 minutes, Wavelength: $225 \mathrm{~nm}$, Lamp: Deuterium

\section{Calibration Curve}

The standard solutions (50-300 ng per respective spot) were applied in triplicate on TLC plate. The plate was developed and scanned as per the chromatographic conditions mentioned above. The peak areas were recorded. Calibration curve of Bacoside A was prepared by plotting peak areas vs. concentrations of Bacoside A applied.

\section{Analytical Procedure}

Methanol extracts of IBV, BV1,BV2, BV3 and standard solution of bacoside A were spotted on a $10 \times 10 \mathrm{~cm}$ precoated TLC plates as $6 \mathrm{~mm}$ wide band and $8 \mathrm{~mm}$ from the bottom by using Linomat V. The plates were developed in a twin trough chamber, under the chromatographic conditions given above, by ascending mode to a distance of $8 \mathrm{~cm}$ under 
Mishra et al., Afr J Tradit Complement Altern Med. (2013) 10(3):390-396 http://dx.doi.org/10.4314/ajtcam.v10i3.1

chamber saturation conditions. After development the plates were dried in air and scanned at $225 \mathrm{~nm}$ for bacoside A by using CAMAG Scanner III. The contents of Bacoside A in IBV, BV1, BV2 and BV3 were calculated from the respective calibration curve.

\section{Results}

SEM analysis of bhasma and pisties showed the reduction in particle size of minerals and metals in the range of 2$5 \mu \mathrm{m}$ (Figure 2). Results of physico-chemical and pharmaceutical parameters have been presented in the table 2. Energy dispersive spectroscopy analysis revealed the elemental compositions of all four samples (Table 3). Gold was found absent in BV2 and BV3. In HPTLC, Bacoside A showed single peak at $0.62 \mathrm{Rf}$. The spot at Rf 0.60 corresponding to Bacoside A was observed in the chromatogram of all samples.

There was no interference from other components present in the formulation. Good correlation was also obtained between standard and samples overlay spectra of Bacoside A (Figure 3) .Calibration curves was prepared by plotting concentrations versus average area of the peak (Fig 4 ). The linear regression analysis of calibration plots of Bacoside A exhibited linear relationship in the range of 50-300ng with the correlation coefficient 0.998 and thus exhibits good linearity between concentration and area (Table 4). Good correlation was also obtained between standard and samples overlay spectra of bacoside A were coloured lines represents the absorption maxima for samples and standard bacoside A(Figure 6).

Recovery study was carried out by spiking the pre-analyzed samples with pure Bacoside A The percentage recovery of bacoside A was found to be $96.06 \%$. The limit of detection was determined by signal to noise ratio which was found to be 10 $\mathrm{ng} / \mathrm{spot}$. The formulation samples were analyzed by the proposed method. The data from Table 5 revealed that the bacoside A contents in IBV, BV1, BV2, BV3 were found as 1094.52 $\pm 38.53,1038.45 \pm 28.71,523.80 \pm 12.43$ and $390.64 \pm 27.80 \mu \mathrm{g} / \mathrm{gm}$ of sample respectively.

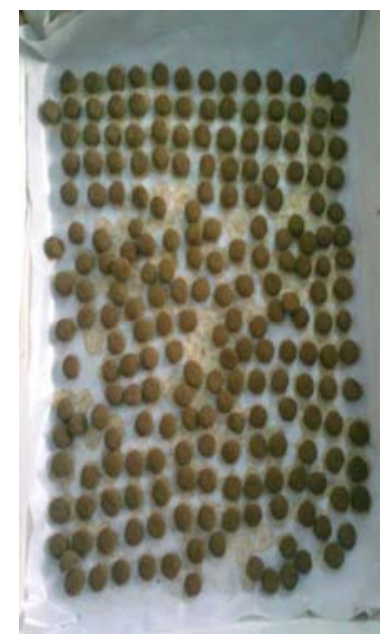

Figure 1: IBV
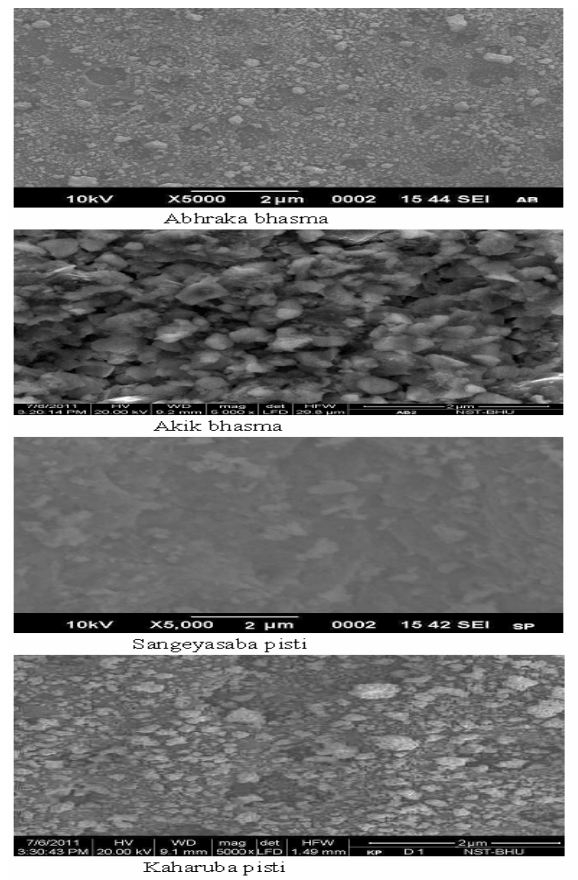

Figure 2: SEM analysis report of bhasma and pisties.
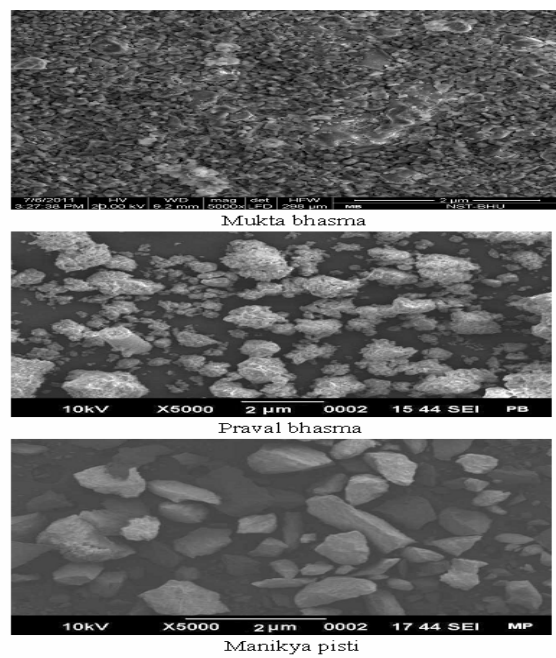

\section{Discussion}

The SEM analysis of bhasma shows reduction in the particle size to 2-5 $\mu \mathrm{m}$ range, which indicates the proper preparation of bhasma and is responsible for high biological activities of these metals and minerals derived substances (Wadekar M.P, et al 2006). Reduction in particle size also facilitates absorption and assimilation of the bhasma in the system (Mohapatra and Jha, 2010). The total ash content, which usually consists of carbonate, silicates, silica, physiological and non physiological ash, was found high in all samples which is due to the presence of mineral and metal derived substances in the formulation (Ahmad J, et al 2012). Physico-chemical parameters evaluated were found to be variable in all marketed formulations in comparison to the standard formulation. Values for BV1 sample were within $\pm 5 \%$ range of IBV while BV2 and BV3 showed variation in many parameters. The quality of raw material used and variation in the preparation method adopted are the expected reasons behind this. Friability was founded more than $1 \%$, which is due to the absence of any binder. These friability values thus indicate that these tablets cannot withstand the stress associated with transportation and dispensing 
Mishra et al., Afr J Tradit Complement Altern Med. (2013) 10(3):390-396 http://dx.doi.org/10.4314/ajtcam.v10i3.1

processes (Akpabio, E. et al 2011).This can result in loss of weight due to friction. Hardness was also very less, which may cause breakdown of vati during transport. These parameters can be modified by the formulation of Brahmi vati. The data of standard formulation (IBV) may be used for standardization of Brahmi vati in future. The EDS analysis revealed the elemental composition of Brahmi vati. The amount of carbon (50.80-54.30\% weight) represents the organic part (plant materials) of the vati. Other than this, the IBV contains Magnesium, Aluminum, Silica, Sulphur, Chloride, Potassium,

Table 2: Results of physico-chemical and pharmaceutical parameters in mean (SD) \pm SEM.

\begin{tabular}{|l|l|l|l|l|}
\hline Parameters & IBV & BV1 & BV2 & BV3 \\
\hline Moisture content (\%) & $1.04(0.35) \pm 0.17$ & $1.08(0.73) \pm 0.32$ & $1.89(0.56) \pm 0.23^{*}$ & $0.96(0.02) \pm 0.08^{*}$ \\
\hline Water soluble extractive (\%) & $12.20(0.66) \pm 0.33$ & $11.88(0.29) \pm 0.40$ & $10.58(0.61) \pm 0.33^{*}$ & $11.45(0.54) \pm 0.35$ \\
\hline Methanol soluble extractive (\%) & $15.87(0.30) \pm 0.15$ & $15.08(0.34) \pm 0.13$ & $11.98(0.46) \pm 0.85^{*}$ & $14.61(0.78) \pm 0.24^{*}$ \\
\hline Ash content (\%) & $11.41(0.37) \pm 0.18$ & $10.95(0.45) \pm 0.19$ & $12.04(0.32) \pm 0.76^{*}$ & $11.22(0.56) \pm 0.41$ \\
\hline Acid insoluble ash (\%) & $1.38(0.25) \pm 0.12$ & $1.44(0.18) \pm 0.27$ & $2.34(0.21) \pm 0.11^{*}$ & $1.41(0.32) \pm 0.15$ \\
\hline$p H$ & $6.45(0.36) \pm 0.18$ & $6.60(0.18) \pm 0.34$ & $7.32(0.80) \pm 0.36^{*}$ & $6.55(0.43) \pm 0.22$ \\
\hline Ether soluble extractive (\%) & $9.47(0.35) \pm 0.17$ & $8.96(0.11) \pm 0.21$ & $6.73(0.46) \pm 0.72^{*}$ & $7.43(0.63) \pm 0.31^{*}$ \\
\hline Sulphated ash (\%) & $13.26(0.82) \pm 0.41$ & $12.66(0.42) \pm 0.84$ & $12.79(0.62) \pm 0.54$ & $13.12(0.25) \pm 0.11$ \\
\hline Crude fiber (\%) & $10.65(0.60) \pm 0.30$ & $11.03(0.13) \pm 0.93$ & $11.47(0.45) \pm 0.21^{*}$ & $10.23(0.61) \pm 0.39$ \\
\hline $\begin{array}{l}\text { Total yeast \& mould count (col/g) } \\
(\text { Stand.limit-10/g) }\end{array}$ & $\begin{array}{l}\text { Within the standard } \\
\text { limit }\end{array}$ & $\begin{array}{l}\text { Within the standard } \\
\text { limit }\end{array}$ & $\begin{array}{l}\text { Within the standard } \\
\text { limit }\end{array}$ & $\begin{array}{l}\text { Within the standard } \\
\text { limit }\end{array}$ \\
\hline $\begin{array}{l}\text { Total aerobic count(col/g) (Stand.limit- } \\
\left.10^{5} / \mathrm{g}\right)\end{array}$ & $\begin{array}{l}\text { Within the standard } \\
\text { limit }\end{array}$ & $\begin{array}{l}\text { Within the standard } \\
\text { limit }\end{array}$ & $\begin{array}{l}\text { Within the standard } \\
\text { limit }\end{array}$ & $\begin{array}{l}\text { Within the standard } \\
\text { limit }\end{array}$ \\
\hline Average weight (g)(Sample size $=10$ vati) & $0.253(0.004) \pm 0.002$ & $0.254(0.007) \pm 0.006$ & $0.258(0.006) \pm 0.007$ & $0.257(0.003) \pm 0.005$ \\
\hline Hardness (kg/cm2) & $0.82(0.20) \pm 0.10$ & $0.78(0.15) \pm 0.32$ & $0.98(0.41) \pm 0.24^{*}$ & $0.76(0.30) \pm 0.21^{*}$ \\
\hline Disintegration time (sec) & $149.5(18.48) \pm 9.24$ & $152.2(18.12) \pm 9.94$ & $159.6(14.23) \pm 8.28^{*}$ & $148(12.59 \pm 11.24$ \\
\hline Friability $(\%)$ & $2.5(0.29) \pm 0.14^{*}$ & $2.6(0.22) \pm 0.15^{*}$ & $2.8(0.36) \pm 0.16^{*}$ & $2.3(0.32) \pm 0.11 *$ \\
\hline
\end{tabular}

* Values out of $\pm 5 \%$ range of IBV.

Table 3: Elemental composition of Brahmi vati in \% weight (IBV, BV1, BV2, BV3)

\begin{tabular}{|c|c|c|c|c|}
\hline & IBV & BV1 & BV2 & BV3 \\
\hline $\mathbf{C}$ & 52.80 & 50.80 & 52.10 & 54.30 \\
\hline $\mathbf{O}$ & 09.40 & 09.70 & $07.30^{*}$ & $07.80^{*}$ \\
\hline $\mathbf{M g}$ & 05.20 & 05.10 & $03.80^{*}$ & $04.20^{*}$ \\
\hline $\mathbf{A l}$ & 03.90 & $05.70^{*}$ & $05.10^{*}$ & $06.80^{*}$ \\
\hline $\mathbf{S i}$ & 09.70 & $10.20^{*}$ & $10.50^{*}$ & $06.80^{*}$ \\
\hline $\mathbf{S}$ & 03.90 & $04.90^{*}$ & $04.70^{*}$ & $04.10^{*}$ \\
\hline $\mathbf{C l}$ & 03.70 & 03.60 & 03.60 & 03.50 \\
\hline $\mathbf{K}$ & 03.90 & $01.40^{*}$ & $03.30^{*}$ & $02.40^{*}$ \\
\hline $\mathbf{C a}$ & 06.20 & $05.80^{*}$ & 06.60 & 07.60 \\
\hline $\mathbf{A u}$ & 00.30 & 00.30 & - & - \\
\hline $\mathbf{H g}$ & 00.10 & $00.50^{*}$ & $01.90^{*}$ & $01.20^{*}$ \\
\hline
\end{tabular}

* Values out of $\pm 5 \%$ range of IBV. 
Mishra et al., Afr J Tradit Complement Altern Med. (2013) 10(3):390-396 http://dx.doi.org/10.4314/ajtcam.v10i3.1

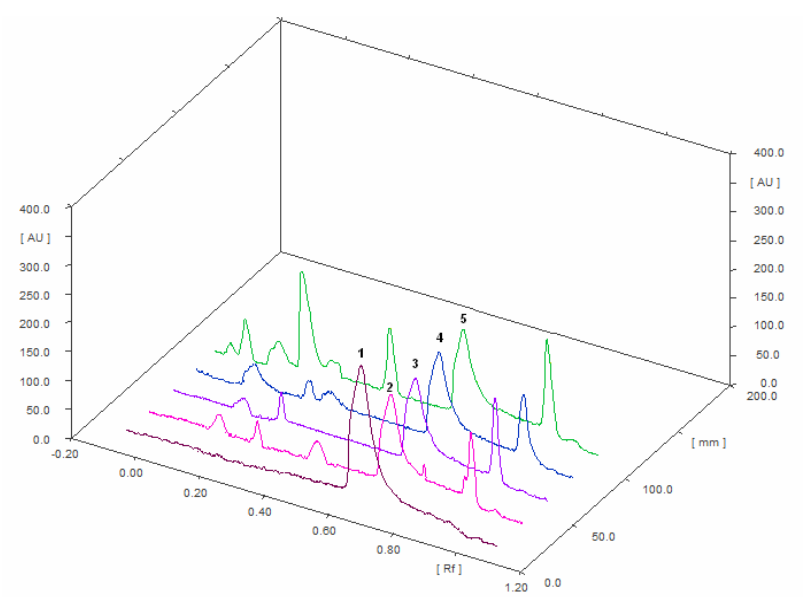

Figure 3: Chromatogram of Bacoside $\mathrm{A}$ and $\mathrm{BV}$

1. Bacoside A, 2. BV1, 3. BV2, 4. BV3, 5. In-house Brahmi vati.

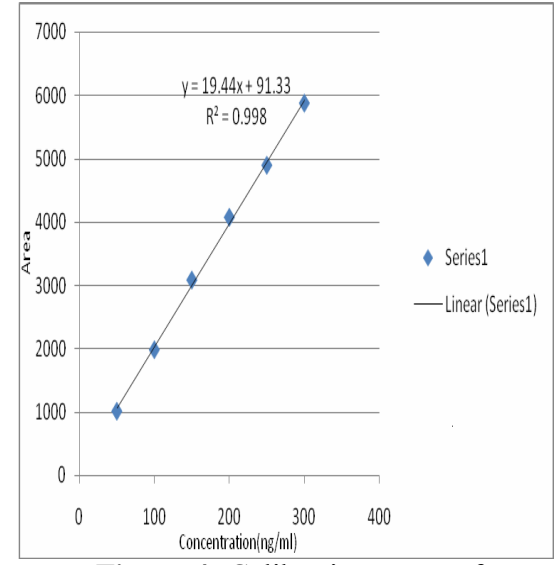

Figure 4: Calibration curve of Bacoside A

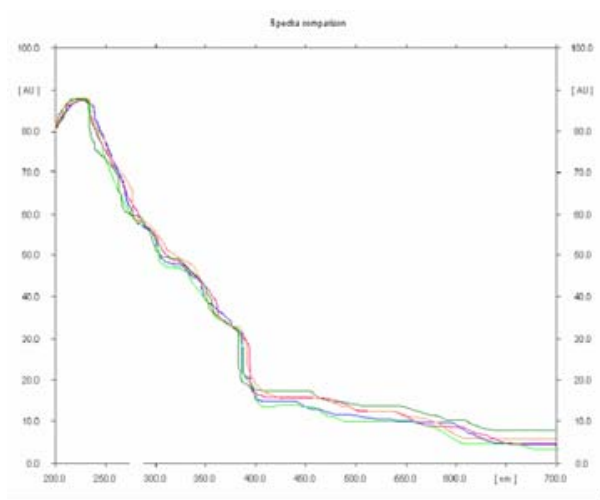

Figure 6: Spectra comparison of bacoside A for samples and standard

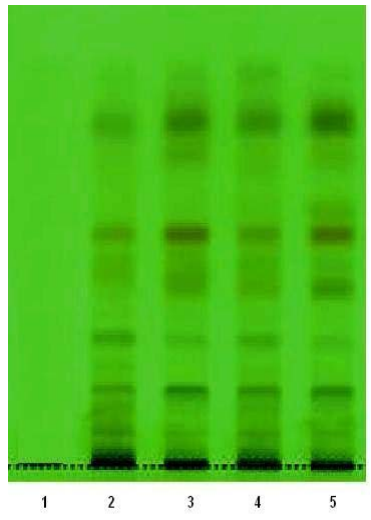

Figure 5: Photo plate scanned at $254 \mathrm{~nm}$ 1. Bacoside A, 2. BV1, 3. BV2, 4. BV3, 5.IBV

Table 4: Bacoside A content in different samples of Brahmi vati

\begin{tabular}{|l|l|l|}
\hline S.No. & Samples & Bacoside A Mean $\pm \mathrm{SD}(\mu \mathrm{g} / \mathrm{gm}$ of BV $)$ \\
\hline 1 & IBV- In-house Brahmi vati & $1094.52 \pm 38.53$ \\
\hline 2 & BV1- Marketed sample 1 & $1038.45 \pm 28.71$ \\
\hline 3 & BV2- Marketed sample 2 & $523.80 \pm 12.43^{*}$ \\
\hline 4 & BV3- Marketed sample 3 & $390.64 \pm 27.80^{*}$ \\
\hline
\end{tabular}

$*$ Values out of $\pm 5 \%$ range of IBV.

Table 5: Results of Recovery study

\begin{tabular}{|l|l|l|l|l|l|l|}
\hline S1.No & $\begin{array}{l}\text { Amount of } \\
\text { sample taken } \\
(\mathrm{mg}) \mathbf{A}\end{array}$ & $\begin{array}{l}\text { Amount of } \\
\text { Bacoside A in } \\
\text { A } \\
(\mathrm{ng}) \mathbf{B}\end{array}$ & $\begin{array}{l}\text { Amount of } \\
\text { Bacoside A } \\
\text { added to A } \\
(\mathrm{ng}) \mathbf{C}\end{array}$ & $\begin{array}{l}\text { Amount of } \\
\text { Bacoside A } \\
\text { taken B+C } \\
(\mathrm{ng}) \mathbf{D}\end{array}$ & $\begin{array}{l}\text { Total Bacoside A } \\
\text { found (Mean } \pm \text { SD, } \\
\text { n=5) } \\
(\mathrm{ng}) \mathbf{E}\end{array}$ & $\begin{array}{l}\text { \% } \\
\text { Recovery } \\
\text { E/DX100 }\end{array}$ \\
\hline 1 & 250 & 277 & 50 & 327 & $311 \pm 8.45$ & 95.10 \\
\hline 2 & 350 & 285 & 100 & 385 & $371 \pm 10.23$ & 96.36 \\
\hline 3 & 450 & 292 & 200 & 492 & $476 \pm 9.38$ & 96.74 \\
\hline
\end{tabular}

Average Recovery: $96.06 \%$

Table 6: Results of Validation Method

\begin{tabular}{|l|l|l|l|l|}
\hline Analytical Method & $\begin{array}{l}\text { Accuracy(\% } \\
\text { recovery) }\end{array}$ & $\begin{array}{l}\text { Precision. } \\
\text { (S.D) }\end{array}$ & Linearity & $\begin{array}{l}\text { Coefficient of } \\
\text { variation\%(CV) }\end{array}$ \\
\hline HPTLC of Bacoside A & $\mathbf{9 6 . 0 6}$ & 0.6884 & $50-300 \mathrm{ng}$ & 0.3564 \\
\hline
\end{tabular}

Calcium, Gold and Mercury .These trace quantities of minerals along may play an important role in the functioning of various enzymes in biological systems and have immunomodulatory functions and thus influence the susceptibility to the course and the outcome of a variety of viral infections (Chaturvedi, U.C. et al 2004). There was absent of Gold in BV1 and 
BV2, which indicates the absence of Swarna bhasma in Brahmi vati which is a very important ingredient of vati and have many pharmacological properties (Singh and Chaudhary, 2011). Mercury was found comparatively in high amount in BV1, $\mathrm{BV} 2$ and BV3( more than $+5 \%$ ). Intake of high amount of mercury can cause memory loss, including Alzheimer like dementia, disruption of fine motor function and decreases rate of fertility etc (Zahir, F. et al 2005). The study revealed that the marketed samples of brahmi vati contain significant amounts of Bacoside A, but only one of three (BV1) in $\pm 5 \%$ range of the standard preparation. This indicates the genuineness of BV1 formulations. Collected from different places, season of collection, storage condition and authenticity of crude herbs affects the yield of the marker compound present in it. This may be the reason behind the variability in the Bacoside A content of these formulations.

The study showed absence of Gold and presence of less amount of Bacoside A in two samples ,BV2 and BV3,which indicates their substandard quality and will lead to reduce their pharmacological properties than claimed in the traditional literatures.

\section{Conclusion}

Brahmi vati was standardized adopting modern analytical procedures and it was found that there are variations in the quality of the formulation prepared and marketed by different manufactures. The data of physico-chemical and elemental analysis of the standard Brahmi vote may be useful for evaluation and standardization. The proposed HPTLC method was found to be rapid, simple and accurate for quantitative estimation of Bacoside A. The method was found to be useful in detecting the genuineness of the formulation and thus suitable to evaluate various formulations of Brahmi vati available in the market.

\section{Acknowledgment}

The authors are thankful to the Director of Indian Institute of Integrative medicine, Jammu, India for providing a gift sample of standard compound.

\section{References}

1. Gold frank, L. Lewin, N. Flomenbaum, N \& Hawland, M.A, (1982) The Pernicious Panacea: Herbal Medicine. Hospital Physician 18:64-87.

2. Vulto, A.G and Smet, P.A.G.M, (1988). Drug used in non-orthodox medicine, In: Meyler's Side Effects of Drugs, Eleventh edition, Published by Elsevier Amsterdam, 999-1005.

3. Bagul, M.S and Rajani, M, (2005).Phytochemical Evaluation of Classical Formulation - A Case Study. Indian Drugs 42 (1): 15 - 19.

4. The Ayurvedic Formulary of India (AFI),( 1976). Part I and II, First Edition, Published by Department of Health, Ministry of Health and Family Welfare, Govt. of India, New Delhi.

5. ICH, Q2A, (1994). Validation of analytical procedure: Methodology, in: Proc. Int. Con. Harmonization, Geneva.

6. ICH, Q2B, (1996). Validation of analytical procedure: Methodology, in: Proc. Int. Con. Harmonization, Geneva.

7. Marker compounds of selected Ayurvedic drugs, (2009) Published by Captain Srinivasa Murti Research Institute for Ayurveda and Siddha Drug Development(CCRAS) \& WHO Country Office for India, New Delhi, 27.

8. Saumy, M.S.E and. Grampurohit, N.D. (2002). Chemical Evaluation of Navayasa churna, Indian Drugs, 39(2): 101 -105 .

9. Patel, K.N,(1996). Solutions to Problems Associated with Herbal Drugs and their Formulations; Pharma Plus 1(1): 9-11.

10. Prakash, B.( 1997). Use of Metals in Ayurvedic Medicines, Indian Journal of History and Sciences, 32(1):1-28.

11. Mohaptra, S. Jha, C.B. (2010). Physicochemical Standardization of Ayurvedic Bhasma (Swarna Makshika Bhasma): an approach to standardization, International Journal of Ayuveda Research, 1(2): 82-86.

12. Mukharjee, P.K, (2002) Quality Control of Herbal Drugs, First Edition, Published by Business Horizons Pharmaceutical Publishers, 192-193.

13. Pattanayaka, P. Mohapatra, P. Jena, R.K. and Panda, S.K. (2011) .Standardization of Sulaharana Yoga: An Ayurvedic tablet formulation. Indian Journal of Pharmaceutical Sciences, 73(1):65-70.

14. Lohar, D.R (2009). Protocol for testing Ayurveda, Siddha and Unani medicines, Published by Government of India Department of AYUSH, Ministry of Health \& Family Welfare, Pharmacopoeial Laboratory For Indian Medicines Ghaziabad, 29.

15. Sudhaparimala1, S. Mullai Kodi, C. Gnanamani, A and Mandal, A.B (2011). Quality Assessment of Commercial Formulations of Tin based Herbal Drug by Physico-chemical Fingerprints, Indian Journal of Science and Technology, 4(12) :1710-1714.

16. Singh, S.K. Gautam, D.N.S. Kumar, M. and Rai, S.B.( 2010). Synthesis, Characterization and Histopathological Study of a Lead-Based Indian Traditional Drug: Naga Bhasma, Indian Journal of Pharmaceutical Sciences, 72(1): 24-30. 
Mishra et al., Afr J Tradit Complement Altern Med. (2013) 10(3):390-396 http://dx.doi.org/10.4314/ajtcam.v10i3.1

17. Wadekar, M.P. Rode C.V. Bendale, Y.N. Patil, K.R. and Prabhune, A.A. (2005) Preparation and characterization of a copper based Indian traditional drug: Tamra bhasma Journal of Pharmaceutical and Biomedical Analysis, 39(5): 951-955.

18. Mohapatra, S. Jha, C.B.(2010) Physicochemical characterization of Ayurvedic bhasma (Swarna makshika bhasma): An approach to standardization, International Journal of Ayurveda Resaerch,1(2): 82-86.

19. Ahmad, J. Showket, R. Kamran, J.N. (2012) Developments of quality standards of Berberis aristata stem bark, 3(2):184- 187

20. Akpabio, E. Jackson, C. Ugwu, C. Etim, M. Udofia, M. (2011) Quality control and in vitro bioequivalence studies on four brands of ciprofloxacin tablets commonly sold in Uyo Metropolis, Nigeria, 3(3):734-741.

21. Chaturvedi, U.C. Shrivastava, R. Upreti, R.K. (2004) Viral infections and trace elements: A complex Interaction, 87(11):1536-154.

22. Singh, N. Chaudhary, A.(2011) Swarna Bhasma and Gold Compounds: an Innovation of Pharmaceutics for Iillumination of Therapeutics, International Journal of Research in Ayurveda and Pharmacy, 3(1):5-9.

23. Zahir, F. Rizwi, S.J. Haq, S.K. Khan, R.H. (2005) Low dose mercury toxicity and human health, 20(2):351-360. 